\title{
Dr. sc. Tamara Slišković
}

Docentica

Sveučilište u Zagrebu

Ekonomski fakultet

E-mail: tamara.sliskovic@efzg.hr

Orcid: https://orcid.org/0000-0001-7925-8909

\section{Dr. sc. Martina Solenički}

Docentica

Sveučilište u Zagrebu

Ekonomski fakultet

E-mail: mnakic@efzg.hr

Orcid: https://orcid.org/0000-0001-6380-1700

\section{Dr. sc. Marija Beg}

Docentica

Sveučilište u Zagrebu

Ekonomski fakultet

E-mail: mbeg@efzg.hr

Orcid: https://orcid.org/0000-0002-7897-8055

\section{0. - GODINA ŠOKOVA - PROCJENA UČINAKA NA CIJENE STANOVA U HRVATSKOJ ${ }^{*}$}

\author{
UDK / UDC: $332.42: 616.2-036.21$
}

JEL klasifikacija / JEL classification: R21, R32, R38, O18

DOI: $10.17818 / \mathrm{EMIP} / 2021 / 2.4$

Izvorni znanstveni rad / Original scientific paper

Primljeno / Received: 2. travnja 2021. / Aprile 2, 2021

Prihvaćeno za tisak / Accepted for publishing: 8. prosinca 2021. / December 8, 2021

\section{Sažetak}

Protekla je godina (2020.) obilježena šokovima koji su u različitim sferama uzdrmali hrvatsko gospodarstvo. U prvom redu, covid-19 pandemija i mjere potpunog/parcijalnog zaključavanja gospodarstva prvotno su usporile ekonomsku aktivnost, a potom i rezultirale rekordno negativnim stopama rasta BDP-a. Neposredno nakon proglašenja svjetske pandemije, glavni grad Hrvatske pogođen je još jednim nepredviđenim šokom u obliku snažnog potresa. U ovom radu procjenjuju se učinci navedenih događaja na cijene stanova na razini Hrvatske, ali $i$ pojedinih regija (Zagreb, Jadran $i$ ostalo). Usporedno se procjenjuje i učinak subvencioniranja stambenih kredita koji nije vezan isključivo za 2020. Hedoničkim modelom procjene traženih $i$ postignutih cijena stanova

\footnotetext{
1* Ovaj rad rezultat je projekta br. 6785 koji financira Hrvatska zaklada za znanost.
} 
utvrđeno je kako pandemija nije značajno povezana s kretanjima cijena stanova, dok se subvencije na stambene kredite mogu dovesti u vezu s rastom cijena na pojedinim segmentima tržišta. Dodatno, potres u Zagrebu je, prema rezultatima procjene, moguće povezati s rastom cijena na segmentu novije izgrađenih stanova.

Ključne riječi: cijene stanova, hedonički model, covid-19, subvencionirani stambeni krediti, potres

\section{UVOD}

Hrvatsku su u 2020. godini obilježili povijesni šokantni događaji.

Prvenstveno se to odnosi na dva različita uzroka šokova, pandemiju koronavirusa te razorne potrese u ožujku i prosincu. Naime, zbog pandemije došlo je do potpunog zatvaranja gospodarstva u ožujku i travnju te su od tada pa sve do danas na snazi određene mjere koje sprečavaju normalno odvijanje svih aktivnosti u gospodarstvu.

Cilj je ovoga rada istražiti kako su navedeni šokovi utjecali na tržište nekretnina, odnosno na cijene stanova. Konkretno, pokušava se pronaći jačina i smjer veze između tzv. lockdowna (zatvaranja gospodarstva) te potresa u ožujku i cijena stanova. U tom kontekstu, zbog nemogućnosti proučavanja posljedica potresa iz prosinca 2020., a koje se očituju u 2021., spomenute se neće proučavati. S druge strane, model će se proširiti na učinak subvencioniranja stambenih kredita koje se u Hrvatskoj jednom godišnje odvija od 2017., dok se u 2020. odvilo u dvama navratima. Budući da navedeno subvencioniranje u teoriji vodi do korekcije u cijeni stanova, korisnim se čini ispitati i taj učinak na cijene stanova u događajima bogatoj 2020.

Empirijska analiza provest će se hedoničkim modelom procjene traženih i postignutih cijena stanova. Hedonički modeli uobičajeno se koriste u analizi cijena na tržištu nekretnina jer uzimaju u obzir kvalitativna obilježja nekretnina. Indeksi cijena procijenjeni ovim modelom superiorni su u odnosu na pokazatelje cijena koji podrazumijevaju samo prosječne ili medijalne cijene stanova. Budući da su cijene stanova hedoničkim modeliranjem korigirane za kvalitativna obilježja pojedinog stana, moguće je pratiti ,čistu“ promjenu cijena stanova.

Rad je strukturiran u šest poglavlja. U drugom dijelu rada daje se detaljniji prikaz šokova u 2020., koji se empirijski istražuju. U trećem dijelu rada prikazuje se teoretska podloga za provođenje istraživanja u kojem se predstavljaju sva relevantna istraživanja vezana uz temu istraživanja. U četvrtom dijelu donosi se prikaz podataka i metodologije, dok se empirijski rezultati i rasprava predstavljaju u petom dijelu. Konačno, u zaključku sažeti su glavni nalazi rada, ograničenja istraživanja i preporuke za daljnja istraživanja na ovom polju. 


\section{DOGAĐANJA NA TRŽIŠTU U 2020.}

Svijet će pamtiti 2020. ponajviše po globalnoj pandemiji novog koronavirusa SARS-CoV-2. Naime, budući da za bolest koju virus uzrokuje, nazvanu covid-19, nije bilo lijeka te da se koronavirus iznimno brzo širi, nacionalne države borile su se različitim metodama kako bi se širenje tog lako prenosivog virusa usporilo. U Hrvatsku je koronavirus ušao 25. veljače 2020., a zbog rasta broja zaraženih, mjere su se pooštravale te se kao početak tzv. lockdowna mogu navesti dva datuma: 21. ožujka, kada je Stožer civilne zaštite Republike Hrvatske donio Odluku o mjeri strogog ograničavanja zadržavanja na ulicama i drugim javnim mjestima (NN 34/2020.), te 23. ožujka, kada je Odlukom o zabrani napuštanja mjesta prebivališta i stalnog boravka u Republici Hrvatskoj (NN 35/2020.) zabranjeno napuštanje mjesta prebivališta i stalnog boravka. Navedene mjere bile su na snazi do kraja travnja, kada se postupno popuštaju, ovisno o epidemiološkoj situaciji u pojedinoj županiji. Do većeg zatvaranja gospodarstva zbog pandemije koronavirusa ponovno je došlo u studenome i prosincu.

Uz globalnu pandemiju, Hrvatsku su u 2020. obilježili i jaki i razorni potresi. Prvi se dogodio 22. ožujka te je pogodio Zagreb i šire zagrebačko područje, a bio je magnitude $M=5.5$. Drugi i treći jaki potresi dogodili su se kod Petrinje, najprije 28. prosinca, magnitude $\mathrm{M}=5.0$, te narednog dana, 29. prosinca, razoran potres magnitude $\mathrm{M}=6.2$.

Cilj je rada ispitati kako su navedeni šokovi utjecali na tržište nekretnina u 2020. Kao početno razdoblje koronavirusne krize uzet će se u obzir zatvaranje gospodarstva u ožujku. Učinci potresa promatrat će se samo na temelju zagrebačkog potresa u ožujku. Naime, dva potresa na petrinjskom području krajem godine odrazila su se vjerojatno na tržište stanova u 2021. te se stoga ne analiziraju u ovom radu.

Dodatno, izuzev vanjskih šokova, za koje se pretpostavlja da su utjecali na tržište stanova, u 2020. dogodila su se i dva interna događaja vezana samo uz to tržište. Naime, 2017. Republika Hrvatska počinje subvencionirati stambene kredite kako bi se olakšalo stambeno zbrinjavanje hrvatskih državljana s konačnim ciljem demografske obnove stanovništva i prekidanja rastućeg trenda iseljavanja stanovništva. Stoga je sama mjera usmjerena na mlade Hrvate do 45 godina koji, da bi se prijavili za subvenciju, najprije moraju pronaći stambenu nekretninu i komercijalnu banku koja bi financirala kredit, a tek nakon što kredit bude odobren, mogu aplicirati za subvenciju. Dodatno, prijavitelj (ili supružnik) ne smije imati u vlasništvu stan ili kuću, odnosno ako ima samo jedan stan ili kuću da je proda radi kupnje veće. Zatim, subvencionira se kredit do iznosa od 100000 EUR, odnosno do 1500 EUR po kvadratu. Stambeni kredit može biti veći od tog iznosa, ali se taj dio ne subvencionira. Postoji uvjet i vezan uz rok otplate kredita koji ne smije biti kraći od 15 godina. Samo subvencioniranje odvija se na temelju otplate dijela stambenog kredita (dijela anuiteta), prvenstveno u prvom razdoblju otplate kredita. Iako se vrsta subvencioniranja 
nije suštinski mijenjala, od 2017. do 2020. mijenjali su se određeni uvjeti subvencioniranja. Tako je u 2017. država pokrivala 50\% mjesečnog anuiteta u prve četiri godine otplate kredita, pri čemu se razdoblje moglo produžiti za dodatne dvije godine ako se u obitelji rodi (ili ako posvoje) dijete. Od 2018. koristi se različita stopa subvencioniranja ovisno o stupnju razvijenosti grada ili općine u kojoj se stan nalazi te se subvencije kreću od najmanje 30\% za najrazvijenije gradove i općine pa do najviše $51 \%$ za najmanje razvijene gradove i općine. Zatim, trajanje subvencioniranja produžilo se na pet godina trajanja kredita, uz dodatne dvije godine za svako novorođeno (ili posvojeno) dijete. Dodatno, od 2019. subvencionira se dodatna godina trajanja kredita za svako dijete koje obitelj već ima.

Karakteristično za navedene subvencije u 2017., 2018. i 2019. jest to da je bio samo jedan krug natječaja, pri čemu je rok za prijavu uvijek suštinski kratko razdoblje od mjesec dana (obično rujan), posebno s obzirom na karakteristike ovog tržišta. U 2020. su, pak, bila dva kruga natječaja (u travnju i rujnu), ali i dalje s kratkim rokom od mjesec dana za prijavu.

\section{TEORETSKA PODLOGA I PREGLED LITERATURE}

Pri modeliranju cijena na stambenom se tržištu ugrubo mogu izdvojiti dva pristupa. Prvi podrazumijeva pristup na makrorazini, odnosno razini većeg tržišta, poput nacionalnoga, gdje se cijene modeliraju s pomoću sveobuhvatnih, makroekonomskih varijabli. Unutar takvog metodološkog okvira kretanje cijena na stambenom tržištu nastoji se objasniti kretanjem makroekonomskih, demografskih i sličnih agregatnih varijabli. Brojna istraživanja u domaćoj i inozemnoj literaturi iznjedrila su skup varijabli koje se mogu smatrati „standardnim“ odrednicama kretanja cijena stambenih nekretnina, kao što su bruto domaći proizvod, zaposlenost, plaće, dostupnost stambenih kredita, kamatne stope, inflacija, broj novosklopljenih brakova itd. Neka od istraživanja, u kojima je implementiran ovaj pristup u domaćoj literaturi, jesu radovi Lovrinčević i Vizek (2008), Posedel i Vizek (2009), Vizek (2010), Dumičić, Čeh Časni i Žmuk (2011), Slišković (2018), Slišković, Nakić i Sekur (2019), Slišković (2019) i Tica (2020). Neki radovi promatraju i učinke varijabli koje su specifične za pojedina nacionalna gospodarstva, pa tako Mikulić i sur. (2021) u model uključuju i varijable vezane uz turizam kako bi se objasnila priuštivost stanovanja u Hrvatskoj.

Drugi je pristup modeliranja cijena na užim geografskim tržištima, gdje se u obzir uzimaju karakteristike konkretnog tržišta, a cijene se modeliraju s pomoću specifičnog skupa varijabli koji se odnosi na konkretno tržište ili $\mathrm{s}$ pomoću skupa varijabli koje opisuju karakteristike nekretnina na tom tržištu. Ovakav pristup, gdje se cijene stambenih nekretnina modeliraju s pomoću njihovih karakteristika naziva se hedonički pristup određivanja cijena stanova, koji se koristi i u ovom radu. Osnovne postavke modela, kao i korištene varijable, detaljnije će se opisati u poglavlju 4. 
Upotreba hedoničkih modela uobičajena je u ekonomskoj analizi kretanja cijena različitih dobara jer ovi modeli uzimaju u obzir kvalitativna obilježja pojedinog dobra. Jedno od prvih istraživanja s primjenom hedoničke metode jest Waughovo (1928) istraživanje cijena poljoprivrednih proizvoda na temelju njihovih kvalitativnih obilježja, poput veličine, oblika, boje, zrelosti i sl. Od prvih istraživanja potrebno je spomenuti i Court (1939) te Grilliches (1961) koji se koriste hedoničkim modeliranjem za izračun indeksa cijena automobila, a konceptualni okvir ovakvog modeliranja postavljaju Lancaster (1966) i Rosen (1974).

Upotreba hedoničkih modela na tržištu stanova posebice je značajna jer je svaki stan specifičan s obzirom na svoja obilježja. Donošenje zaključaka o kretanju na tržištu nekretnina isključivo na osnovi prosječnih ili medijalnih cijena nekretnina koje objavljuju agencije za promet nekretninama može biti zavaravajuće jer one ne uzimaju u obzir kvalitativna obilježja prodanih stanova koja mogu značajno utjecati na konačnu cijenu stana. Ako je u nekom razdoblju prodan neuobičajeno velik broj iznadprosječno ili ispodprosječno kvalitetnih nekretnina, takvi pokazatelji nisu u mogućnosti eliminirati pristranost $\mathrm{u}$ podacima. Hedonički modeli korigiraju cijene nekretnina za kvalitetu nekretnina, zbog čega je moguće pratiti ,čistu“ promjenu cijena nekretnina između dvaju razdoblja.

Cijeli je spektar obilježja na temelju kojih se stambene nekretnine razlikuju, ali ih je moguće klasificirati u dvije osnovne kategorije (Hill, 2011): fizička ili unutarnja obilježja, poput broja soba, površine, broja kupaonica i sl., te lokacijska obilježja koja podrazumijevaju pripadnost nekretnine određenoj regiji, određenom dijelu grada, udaljenost nekretnine od centra ili od određenih sadržaja i sl. Međutim, gotovo je nemoguće identificirati sva obilježja nekretnine koja bi se mogla primjenjivati univerzalno te se prilikom njihova odabira istraživači vode specifičnostima pojedinog tržišta nekretnina, dostupnošću podataka (što je vrlo često ograničavajući faktor) te u konačnici svrhom istraživanja. Lokacija je svakako jedna od ključnih odrednica cijena nekretnina, a Sirmans, MacDonald, MacPherson i Zietz (2006) ističu devet unutarnjih obilježja koja se najčešće pojavljuju u modeliranju cijena nekretnina: površina nekretnine, površina zemljišta, starost nekretnine, broj soba, broj kupaonica, kao i to ima li nekretnina garažu, bazen, kamin i klima-uređaj.

Ključna ideja hedoničkih modela jest pretpostavka da svako pojedinačno obilježje nekretnine donosi određen stupanj zadovoljstva subjektima na stambenom tržištu i svako od tih obilježja ima svoju tzv. implicitnu cijenu. Ukupna tržišna cijena stambene jedinice tada je jednaka zbroju cijena svakog od obilježja stambene jedinice (McDonald i McMillen, 2007). Implicitne cijene pojedinih obilježja stambene jedinice moguće je odrediti hedoničkim modeliranjem tako da se regresira cijena stambene jedinice na veći broj obilježja, pri čemu se u većini istraživanja koristi semilogaritamski model:

$$
\ln P=\beta_{0}+\beta_{1} X_{1}+\beta_{2} X_{2}+\cdots+\beta_{n} X_{n}+\varepsilon
$$

pri čemu su $P$ vektor cijena nekretnina, a $X_{n}$ vektori obilježja koja je moguće grupirati po različitim kriterijima (npr. lokacijskim, kvalitativnim, 
socioekonomskim itd.). Iako se ponekad koriste i linearni modeli, semilogaritamski modeli bolje opisuju stvarne podatke od linearnih modela prema McDonaldu i McMillenu (2007), a primjenjivali su se i u brojnim istraživanjima (Yiu i Tam, 2004; Zietz, Zietz i Sirmans, 2008; Ottensmann, Payton i Man, 2008; Keskin, 2008; Kunovac, Đozović, Lukinić i Pufnik, 2008; Kunovac i Kotarac, 2019).

Modeliranje hedoničkih indeksa cijena nekretnina u Hrvatskoj seže unatrag 15-ak godina. Jedno od prvih istraživanja s ciljem utvrđivanja regionalnih razlika na tržištu nekretnina u Hrvatskoj provele su Botrić i Kordej de Villa (2005) koje, osim makroekonomskih varijabli, u model uključuju i unutarnja te lokacijska obilježja nekretnina. Velik broj kvalitativnih obilježja nekretnina kao determinante njihovih cijena $u$ istraživanje uključuju Kunovac i sur. (2008). Njihov hedonički indeks cijena nekretnina (koji se temelji na podacima Burze nekretnina) do 2015. bio je ključni pokazatelj kretanja na hrvatskom tržištu nekretnina dok DZS nije počeo objavljivati indeks cijena stambenih nekretnina 2015. Osim lokacije (pripadnost nekretnine pojedinoj od četiriju identificiranih regija ili, pak, gradskoj četvrti u slučaju Grada Zagreba), kao determinante cijena nekretnina uzimaju u obzir i površinu nekretnine $\left(\mathrm{u} \mathrm{m}^{2}\right)$ te unutarnja obilježja nekretnine, poput broja soba, godine izgradnje, vremena prodaje, vrste nekretnine, grijanja i sl. Unaprijeđeni hedonički indeks cijena koji se zasniva na podacima Porezne uprave predstavljen je u Kunovac i Kotarac (2019), a uzima u obzir minimalna tražena obilježja: lokaciju, vrijeme prodaje, godinu izgradnje, vrstu nekretnine (kuća ili stan), površinu i cijenu. Kao lokacijski faktor uzimaju u obzir pripadnost nekretnine regiji (tri regije: Grad Zagreb, Jadran i ostalo) te dodatno pripadnost nekretnine podregijama (županiji ili gradu). Slišković i Sekur (2020) korištenjem hedoničkog modela konstruiraju indeks cijena nekretnina za Hrvatsku te četiri regije (Grad Zagreb, srednji i južni Jadran, Istra i sjeverni Jadran i ostalo). Varijable uključene u model jesu cijena stambene nekretnine, lokacija, površina, broj soba, godina izgradnje i vrijeme prodaje, a konstruirana su dva indeksa prvi koji se temelji na traženim cijenama, a drugi na postignutim cijenama nekretnina.

Ključni je cilj ovog istraživanja ocijeniti učinak šokova iz 2020. na hrvatsko tržište nekretnina. Budući da su ovi događaji relativno svježi, njihov utjecaj još uvijek nije istražen, a posebice ne u okviru hedoničkog modeliranja cijena nekretnina. Kunovac i Kotarac (2020) analiziraju učinke pandemije i potresa na tržište nekretnina u Zagrebu u prvoj polovini 2020. te zaključuju da su pandemija i potres istovremeno utjecali na cijene i broj prodanih nekretnina $u$ Zagrebu. Iako je došlo do pada broja prodanih nekretnina (22\% u odnosu na isto razdoblje godinu ranije), cijene nekretnina u prvoj polovini 2020. i dalje su rasle. Ističu da smanjenu potražnju za nekretninama u centru grada ne treba pripisivati isključivo potresu jer je trend povećane atraktivnosti života izvan središta grada krenuo ranije, a dodatno je potaknut pandemijom. U konačnici zaključuju kako treba imati na umu da pandemija i potres imaju slične osnovne učinke na ponudu, potražnju i cijene nekretnina; oba događaja javljaju se gotovo istovremeno, zbog čega je teško razdvojiti i posebno ocijeniti učinak pandemije od učinka potresa, 
stoga je promjene na zagrebačkom tržištu nekretnina potrebno interpretirati kao rezultat agregiranog učinka obaju događaja.

Dodatno, od 2017. u Hrvatskoj je uveden program subvencioniranja stambenih kredita koji se također odrazio na obujam transakcija na tržištu i na cijene stambenih nekretnina te će se u ovom istraživanju ocijeniti i njegov učinak. Ocjenu učinaka programa subvencioniranja stambenih kredita u svojim istraživanjima proveli su Kunovac i Žilić (2020) te Tica (2020). Kunovac i Žilić (2020) u okviru hedoničkog modela s pomoću studije događaja dokumentiraju kako je uvođenje subvencioniranja dovelo do koncentracije stambenih transakcija u mjesecu kada su se predavali zahtjevi za subvencioniranje te da je navedena državna mjera uskoro činila $10 \%$ svih rezidencijalnih transakcija u Hrvatskoj. Sami rezultati provedene empirijske analize u Kunovac i Žilić (2020) pokazuju da su se cijene stanova povećale u razdoblju oko uvođenja subvencije, no prvenstveno u bogatijim regijama u kojima je tržište stanova općenito aktivnije i gdje je stambena ponuda manje elastična. Tica (2020) istražuje utjecaj subvencioniranja stambenih kredita, uzimajući u obzir makroekonomske odrednice kretanja cijena stambenih nekretnina (mjerenih indeksom cijena stambenih nekretnina). Pronalazi da je u razdoblju nakon uvođenja programa subvencioniranja, stopa rasta cijena stambenih nekretnina u Gradu Zagrebu bila između 3 i 10 postotnih bodova godišnje veća od onoga što impliciraju ekonomski fundamenti, dok za druge regije (Jadran i ostalo) ne pronalazi dokaze o statističkoj značajnosti subvencioniranja stambenih kredita.

Slijedom navedenih istraživanja, u ovom istraživanju koristila se podjela Hrvatske na tri regije prema Kunovac i Kotarac (2019), a pri modeliranju upotrebljavale su se varijable istaknute u Kunovac i Kotarac (2019) te Slišković i Sekur (2020). Također, slijedom Slišković i Sekur (2020), analiza je provedena posebno za tražene, a posebno za postignute cijene nekretnina. Budući da do sada nisu detaljnije istraživani utjecaji šokova iz 2020. na hrvatsko tržište nekretnina, ključni doprinos ovog istraživanja proizlazi upravo iz ocjene učinaka zagrebačkog potresa i covid-19 pandemije na hrvatsko tržište nekretnina.

\section{PODACI I METODOLOGIJA}

Analiza se temelji na bazi podataka kupljenoj od Burze nekretnina $\mathrm{u}$ svrhu ovog istraživanja. Baza podataka sadrži osnovne podatke o stanovima koji su se oglašavali i prodavali na području Hrvatske u razdoblju od 2010. do 2020., a koje Burza nekretnina ima evidentirane. Ovdje treba naglasiti kako Burza nekretnina na posjeduje podatke o svim transakcijama koje su realizirane na području Hrvatske, već isključivo onima koje su im prijavile pojedine agencije koje posreduju pri kupoprodajama stambenih nekretnina.

Baza podataka u svojem izvornom obliku sadrži podatke o lokaciji stana (županija, grad ili dio grada u slučaju Zagreba), traženim i postignutima cijenama, vremenu prodaje, tlocrtnoj površini, katu na kojem se stan nalazi, ukupnom broju 
katova, godini izgradnje, orijentaciji, broju soba i pojedinim energetskim karakteristikama (energetski certifikat i vrsta grijanja). Za većinu stanova u bazi postojali su podaci o traženoj i postignutoj cijeni kvadratnog metra, lokaciji, godini izgradnje, površini, broju soba i datumu prodaje. U svrhu što bolje reprezentativnosti uzorka, preostale varijable (za koje je postojao relativno manji broj promatranja) isključene su iz ovog istraživanja. Pojedine su korištene varijable modificirane. Primjerice, varijabla godina izgradnje modificirana je u varijablu kojom se stan klasificira kao novija ili starija gradnja. Također, u istraživanje uključene su varijable kojima se nastoje aproksimirati već ranije opisani događaji, za koje se smatra da imaju potencijalni učinak na cijene stanova.

Podaci su uključeni u hedonički model ovisno o prirodi varijable kao numeričke (tražene i postignute cijene stanova, površina i broj soba) ili binarne (dummy) varijable. Osnovne varijable, koje se koriste u većini procijenjenih modela, navedene su i opisane u Tablici 1.

Tablica 1.

Varijable korištene $\mathrm{u}$ analizi

\begin{tabular}{|c|c|c|}
\hline Varijabla & Oznaka & Opis \\
\hline \multicolumn{3}{|c|}{ Zavisne varijable } \\
\hline $\begin{array}{l}\text { Tražena } \\
\text { cijena }\end{array}$ & $\mathrm{P} 1$ & Tražena cijena stana u eurima po kvadratnom metru \\
\hline $\begin{array}{l}\text { Postignuta } \\
\text { cijena }\end{array}$ & $\mathrm{P} 2$ & Ostvarena cijena stana u eurima po kvadratnom metru \\
\hline \multicolumn{3}{|c|}{ Nezavisne varijable } \\
\hline Površina & M2 & Veličina stana u kvadratnim metrima \\
\hline Broj soba & SOBE & Broj soba koji uključuje dnevnu sobu i spavaće sobe \\
\hline Novogradnja & $\begin{array}{l}\text { NOVOGR } \\
\text { ADNJA }\end{array}$ & $\begin{array}{l}\text { Binarna varijabla koja poprima vrijednost } 1 \text { ako je nekretnina prodana } \\
\text { u godini kada je izgrađena ili u sljedećoj godini nakon izgradnje }(0 \mathrm{u} \\
\text { svim ostalim varijantama) }\end{array}$ \\
\hline Zagreb & $\mathrm{ZG}$ & $\begin{array}{l}\text { Binarna varijabla koja poprima vrijednost } 1 \text { ako se stan nalazi u Gradu } \\
\text { Zagrebu, a } 0 \text { u slučaju ostalih regija }\end{array}$ \\
\hline Jadran & JADRAN & $\begin{array}{l}\text { Binarna varijabla koja poprima vrijednost } 1 \text { ukoliko se stan nalazi u } \\
\text { regiji Jadran, a } 0 \text { u slučaju ostalih regija. Jadranska regija obuhvaća } \\
\text { Istarsku, Ličko-senjsku, Primorsko-goransku, Splitsko-dalmatinsku, } \\
\text { Šibensko-kninsku, Zadarsku i Dubrovačko-neretvansku županiju }\end{array}$ \\
\hline Regija Ostalo & OSTALO & $\begin{array}{l}\text { Binarna varijabla koja poprima vrijednost } 1 \text { ako se stan nalazi u regiji } \\
\text { Ostalo, a } 0 \text { u slučaju ostalih regija. Regija Ostalo obuhvaća Krapinsko- } \\
\text { zagorsku, Bjelovarsko-bilogorsku, Karlovačku, Osječko-baranjsku, } \\
\text { Varaždinsku i Zagrebačku županiju }\end{array}$ \\
\hline $\begin{array}{l}\text { Godina } \\
\text { prodaje }\end{array}$ & GODINA & $\begin{array}{l}\text { Binarna varijabla s } 11 \text { modaliteta kojom se opisuje godina u kojoj je } \\
\text { stan prodan na tržištu. Primjerice, modalitet Y2020 poprima vrijednost } \\
1 \text { ako je stan prodan u 2020., a vrijednost } 0 \text { u preostalim slučajevima }\end{array}$ \\
\hline $\begin{array}{l}\text { Šok } \\
\text { pandemije }\end{array}$ & COVID & $\begin{array}{l}\text { Binarna varijabla koja poprima vrijednost } 1 \text { ako je stan prodan od } \\
\text { početka ožujka na dalje (nastoji se obuhvatiti približan početak } \\
\text { pandemije u Hrvatskoj), a } 0 \text { ako je stan prodan ranije }\end{array}$ \\
\hline $\begin{array}{l}\text { Subvencije } \\
\text { na stambene } \\
\text { kredite }\end{array}$ & APN & $\begin{array}{l}\text { Binarna varijabla koja poprima vrijednost } 1 \text { ako je stan prodan u } \\
\text { mjesecu kada je bio otvoren natječaj za subvencije i u mjesecu prije } \\
\text { toga. a } 0 \text { u preostalim slučajevima }\end{array}$ \\
\hline Šok potresa & POTRES & $\begin{array}{l}\text { Binarna varijabla koja poprima vrijednost } 1 \text { ukoliko je stan prodan } \\
\text { nakon 22. 3. 2020. (nastoji se obuhvatiti učinak zagrebačkog potresa na } \\
\text { cijene stanova u Zagrebu i okolici), a } 0 \text { ukoliko je stan prodan ranije }\end{array}$ \\
\hline
\end{tabular}

Izvor: Izrada autorica 
Baza podataka sadrži informacije o 6167 stanova. U prvom koraku procijenjen je sveobuhvatni model na razini Hrvatske, a potom su procijenjeni modeli za svaku od triju definiranih regija. Distribucija promatranja po regijama ilustrirana je na Slici 1. Vidljivo je da Grad Zagreb, kao najfrekventnije tržište u Hrvatskoj, obuhvaća gotovo $70 \%$ ukupnog broja stanova. Ostale regije bilježe relativno manji broj opservacija, no uzorci se mogu smatrati reprezentativnima za provođenje empirijske analize.

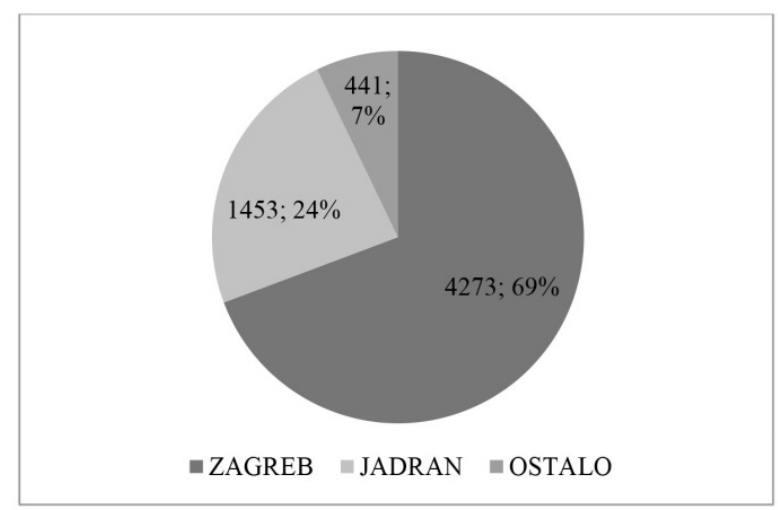

*Napomena: Regija Zagreb odnosi se na Grad Zagreb; regija Jadran obuhvaća Splitsko-dalmatinsku, Dubrovačko-neretvansku, Šibensko-kninsku, Zadarsku, Istarsku, Ličko-senjsku i Primorsko-goransku županiju; regija Ostalo obuhvaća Krapinsko-zagorsku, Bjelovarsko-bilogorsku, Karlovačku, Osječkobaranjsku, Varaždinsku i Zagrebačku županiju.

Slika 1. Distribucija podataka o stanovima u korištenoj bazi prema regijama (2010. - 2020.)

Izvor: izrada autorica prema podacima Burze nekretnina

U drugoj fazi istraživanja procijenjeni su modeli za pojedine regije. Najsloženiji zadatak u tom koraku odnosio se na oblikovanje varijabli kojima se pobliže određuje lokacija stana unutar regije. U tu svrhu, lokacija unutar regija Jadran i Ostalo aproksimirana je smještajem stana u pojedinoj županiji, a unutar regije Grad Zagreb lokacijom u gradskoj četvrti/kvartu. Podjela na lokacijske varijable, zajedno s distribucijom podataka u pojedinim lokacijama, prikazana je u tablicama 2., 3. i 4.

Tablica 2.

Podjela regije Jadran na preciznije lokacije (županije)

\begin{tabular}{|c|c|c|c|c|}
\hline Varijabla & SPLITDAL & DUBNER & SIBKNIN & ZAD \\
\hline Broj opservacija & 398 & 189 & 183 & 163 \\
\hline Opis & Splitsko-dalmatinska & Dubrovačko-neretvanska & Šibensko-kninska & Zadarska \\
\hline Varijabla & IST & LICSENJ & PRIMGOR & \\
\hline Broj opservacija & 307 & 51 & 162 & \\
\hline Opis & Istarska & Ličko-senjska & Primorsko-goranska & \\
\hline
\end{tabular}

Izvor: Izrada autorica 
Tablica 3 .

Podjela regije Ostalo na preciznije lokacije (̌̌upanije)

\begin{tabular}{|c|c|c|c|}
\hline Varijabla & KRAZAG & BJELBIL & KARL \\
\hline Broj opservacija & 24 & 175 & 63 \\
\hline Opis & Krapinsko-zagorska & Bjelovarsko-bilogorska & Karlovačka \\
\hline Varijabla & OSBAR & VAR & ZAGR \\
\hline Broj opservacija & 67 & 16 & 96 \\
\hline Opis & Osječko-baranjska & Varaždinska & Zagrebačka \\
\hline
\end{tabular}

Izvor: Izrada autorica

Tablica 4.

Podjela regije Grad Zagreb na preciznije lokacije (kvartovi/gradske četvrti)

\begin{tabular}{|c|c|c|c|c|}
\hline Varijabla & DMAKSIMIR & DNZISTOK & DNZZAPAD & $\begin{array}{c}\text { DPESCENIC } \\
\text { A }\end{array}$ \\
\hline Broj opservacija & 363 & 192 & 236 & 280 \\
\hline Opis & Maksimir & Novi Zagreb-istok & $\begin{array}{c}\text { Novi Zagreb- } \\
\text { zapad }\end{array}$ & $\begin{array}{c}\text { Pešćenica- } \\
\text { Žitnjak }\end{array}$ \\
\hline Varijabla & DMEDVESCAK & DZAPAD & DPODSLJEME & DOSTALO \\
\hline Broj opservacija & 250 & 452 & 148 & 85 \\
\hline Opis & $\begin{array}{c}\text { Gornji grad i } \\
\text { Medveščak }\end{array}$ & $\begin{array}{c}\text { Stenjevec i } \\
\text { Podsused-Vrapče }\end{array}$ & $\begin{array}{c}\text { Podsljeme i } \\
\text { Gračani }\end{array}$ & $\begin{array}{c}\text { Buzin, Ivanja } \\
\text { Reka, Odra i } \\
\text { Sesvete }\end{array}$ \\
\hline Varijabla & DTRESNJVKASJE & DTRNJE & DDONJIGRAD & $\begin{array}{c}\text { DDUBRAVA } \\
\text { Droj opservacija }\end{array}$ \\
\hline Opis & Trešnjevka sjever & Trnje & $\begin{array}{c}\text { Donji grad i } \\
\text { Centar }\end{array}$ & $\begin{array}{c}\text { Gornja i Donja } \\
\text { Dubrava }\end{array}$ \\
\hline Varijabla & DTRESNJEVKAJUG & DCRNOMEREC & & \\
\hline Broj opservacija & 386 & 364 & & \\
\hline Opis & Trešnjevka jug & Črnomerec & & \\
\hline
\end{tabular}

Izvor: Izrada autorica

Za procjenu učinaka svih spomenutih internih karakteristika, ali i eksternih šokova na cijene stanova, koristio se standardni hedonički model, gdje je zavisna varijabla logaritam cijene po kvadratnom metru, a nezavisne varijable izražene u razinama. Model je sličan onima predstavljenima u Kunovac i sur. (2008), kao i Slišković i Sekur (2020) te ima općeniti oblik:

$$
\begin{aligned}
& \ln p_{j, i}=\alpha+\sum_{j=1}^{m-1} \beta_{j} X_{i j}+\sum_{j=1}^{l} \gamma_{j} W_{i j}+\sum_{j=2}^{T} \delta_{j} D_{i j}+\sum_{j=1}^{k} \theta_{j} S_{i j}+\varepsilon_{i,} \\
& =1,2, \ldots, N
\end{aligned}
$$

Zavisna varijabla $(P)$ ima dva modaliteta:

$$
P=\{P 1 \text { (tražene cijene) } P 2 \text { (postignute cijene) }\}
$$


stoga se posebno procjenjuju modeli za tražene i postignute cijene. $X_{j}$ predstavlja vektor lokacijskih varijabli s $m$ modaliteta. $W_{i j}$ je matrica varijabli koje opisuju kvalitativne karakteristike stanova. $D_{i j}$ obuhvaća vremenske indikator varijable, dok $S_{i j}$ obuhvaća eksterne šokove na koje je ovo istraživanje posebno usredotočeno.

Najširi oblik modela koji je procijenjen za cijelu Hrvatsku ima oblik:

$$
\begin{array}{rl}
\ln P_{i}=\beta_{0}+\beta_{1} Z A G & R E B_{i}+\beta_{2} J A D R A N_{i} \\
& +\beta_{3} M 2_{i}+\beta_{4} S O B E_{i}+\beta_{4} \text { NOVOGRADNJA }+\beta_{5} \text { COVID }_{i} \\
& +\beta_{6} A P N_{i}+\sum_{j=2}^{11} \delta_{j} D_{j}+\varepsilon_{i}
\end{array}
$$

U svrhu ispitivanja robusnosti rezultata procijenjeno je više modela. U prvom redu, slijedeći već potvrđeni rezultat postojećih istraživanja kako vremenska dimenzija znatno pridonosi fluktuacijama cijena, procijenjeni su modeli koji u sebi sadrže samo vrijeme prodaje (bez šokova). Izostavljanje vremenske dimenzije rezultiralo bi time da bi šokovi preuzeli cjelokupan utjecaj koji proizlazi iz promjene vrijednosnih odnosa na tržištu, stoga je uključivanje vremena prodaje $u$ model bilo neupitno. Šokovi su se potom procjenjivali $u$ posebnim modelima, a pri tome treba naglasiti kako su za sva tržišta procijenjeni učinci pandemije i subvencioniranja stambenih kredita, dok se učinak potresa promatrao samo ondje gdje je potres imao izravan učinak (tržište Zagreba i okolice). U skladu sa svim navedenim, modeli za regije međusobno su se razlikovali u varijablama lokacije i varijablama eksternih šokova.

\section{RASPRAVA O REZULTATIMA ANALIZE}

Prvi korak u analizi bila je procjena modela za cjelokupno hrvatsko tržište (Tablica 5.). Procjene su pokazale kako nema značajnih razlika u zaključcima koji proizlaze iz modela traženih i postignutih cijena, stoga ih nema potrebe posebno interpretirati. Većina rezultata $u$ skladu je s početnim očekivanjima i logikom stambenog tržišta u Hrvatskoj. U prvom redu, razvidno je kako je lokacija iznimno značajan čimbenik cijena stanova te da su one na „atraktivnijim“ tržištima (Zagreb i Jadran) u prosjeku statistički značajno više od cijena stanova u regiji Ostalo. Statistički značajan pozitivan učinak na prosječnu cijenu kvadratnog metra imaju i karakteristika novogradnje, kao i svaka dodatna soba. Kao i u većini već provedenih istraživanja za hrvatska tržišta, pokazalo se do površina ima zanemarivo mali utjecaj. Naime, procijenjeni parametar uz varijablu površine statistički je značajan, ali je njegova vrijednost zanemarivo mala i jako blizu nuli u apsolutnom iznosu. Što se tiče učinaka šokova, ni u jednoj procjeni nije potvrđena statistička značajnost varijabli COVID i APN. Taj rezultat nije toliko neočekivan s obzirom na to da je pretpostavka kako niti pandemija koronavirusa niti subvencije na stambene kredite nisu imale jednak učinak na 
stambena tržišta u svim dijelovima Hrvatske, što se naknadno ispitivalo u drugoj fazi istraživanja.

Tablica 5 .

Rezultati procijenjenog hedoničkog modela za Hrvatsku

\begin{tabular}{|c|c|c|c|c|c|c|c|c|}
\hline \multirow{2}{*}{$\begin{array}{l}\text { Varijabla } \\
\downarrow \\
\text { Model } \rightarrow\end{array}$} & \multicolumn{4}{|c|}{$\begin{array}{c}\text { Zavisna varijabla: log (P1) (logaritam } \\
\text { tražene cijene) }\end{array}$} & \multicolumn{4}{|c|}{$\begin{array}{c}\text { Zavisna varijabla: } \log (\text { P2) (logaritam } \\
\text { postignute cijene) }\end{array}$} \\
\hline & 1 & 2 & 3 & 4 & 1a & $2 \mathrm{a}$ & $3 a$ & $4 a$ \\
\hline C & $6,97 * * *$ & $6,97 * * *$ & $6,97 * * *$ & $6,97 * * *$ & $6,89 * * *$ & $6,89 * * *$ & $6,89 * * *$ & $6,89^{* * *}$ \\
\hline ZAGREB & $0,50 * * *$ & $0,50 * * *$ & $0,50 * * *$ & $0,50 * * *$ & $0,50 * * *$ & $0,50 * * *$ & $0,50 * * *$ & $0,50 * * *$ \\
\hline JADRAN & $0,53 * * *$ & $0,53^{* * *}$ & $0,53 * * *$ & $0,53 * * *$ & $0,54 * * *$ & $0,54 * * *$ & $0,54 * * *$ & $0,54 * * *$ \\
\hline M2 & $0,00 * * *$ & $0,00^{* * *}$ & $0,00 * * *$ & $0,00 * * *$ & $0,00^{*}$ & $0,00^{* *}$ & $0,00^{*}$ & $0,00 * * *$ \\
\hline SOBE & $0,03 * * *$ & $0,03 * * *$ & $0,03 * * *$ & $0,03 * * *$ & $0,02 * * *$ & $0,02 * * *$ & $0,02 * * *$ & $0,02 * * *$ \\
\hline NOVOGRADNJA & $0,07 * * *$ & $0,07 * * *$ & $0,07 * * *$ & $0,07 * * *$ & $0,09 * * *$ & $0,09 * * *$ & $0,09^{* * *}$ & $0,09 * * *$ \\
\hline Y2011 & $-0,05 * * *$ & $-0,05 * * *$ & $-0,05 * * *$ & $-0,05 * * *$ & $-0,05 * * *$ & $-0,05^{* * *}$ & $-0,05^{* * *}$ & $-0,05 * * *$ \\
\hline Y2012 & $-0,06 * * *$ & $-0,06 * * *$ & $-0,06 * * *$ & $-0,06 * * *$ & $-0,06^{* *}$ & $-0,06^{* *}$ & $-0,06 * *$ & $-0,06^{* *}$ \\
\hline Y2013 & $-0,16 * * *$ & $-0,16 * * *$ & $-0,16 * * *$ & $-0,16 * * *$ & $-0,16^{* * *}$ & $-0,16^{* * *}$ & $-0,16^{* * *}$ & $-0,16 * * *$ \\
\hline Y2014 & $-0,18 * * *$ & $-0,18 * * *$ & $-0,18 * * *$ & $-0,18 * * *$ & $-0,17^{* * *}$ & $-0,17 * * *$ & $-0,17 * * *$ & $-0,17 * * *$ \\
\hline Y2015 & $-0,20 * * *$ & $-0,20 * * *$ & $-0,20 * * *$ & $-0,20 * * *$ & $-0,18^{* * *}$ & $-0,18^{* * *}$ & $-0,18 * * *$ & $-0,18 * * *$ \\
\hline Y2016 & $-0,26 * * *$ & $-0,26 * * *$ & $-0,26 * * *$ & $-0,26 * * *$ & $-0,23 * * *$ & $-0,23 * * *$ & $-0,23 * * *$ & $-0,23 * * *$ \\
\hline Y2017 & $-0,10^{* * *}$ & $-0,10 * * *$ & $-0,10^{* * *}$ & $-0,10 * * *$ & $-0,03$ & $-0,03$ & $-0,03$ & $-0,03$ \\
\hline Y2018 & $-0,15 * * *$ & $-0,15 * * *$ & $-0,15 * * *$ & $-0,15 * * *$ & $-0,08 * *$ & $-0,08 * *$ & $-0,08^{* *}$ & $-0,08 * *$ \\
\hline Y2019 & $-0,09 * *$ & $-0,10^{* *}$ & $-0,09^{* *}$ & $-0,10^{* *}$ & $-0,06$ & $-0,07$ & $-0,06$ & $-0,07$ \\
\hline Y2020 & $0,06 * * *$ & $0,04 * * *$ & $0,04 * * *$ & $0,06 * * *$ & $0,05 * * *$ & $0,04 * * *$ & $0,05 * * *$ & $0,04 * * *$ \\
\hline COVID & $-0,02$ & - & - & $-0,02$ & 0,00 & - & - & 0,00 \\
\hline APN & $-0,01$ & - & $-0,01$ & - & $-0,02$ & - & $-0,02$ & - \\
\hline ADJ $R^{2}$ & 0,29 & 0,29 & 0,29 & 0,29 & 0,26 & 0,26 & 0,26 & 0,26 \\
\hline
\end{tabular}

Napomena: Zvjezdice ukazuju na odbacivanje nulte hipoteze o neznačajnosti procijenjenog parametra $(\beta=0)$ na razinama statističke signifikantnosti od $1 \%(* * *), 5 \%(* *)$ i $10 \%\left(^{*}\right)$.

\section{Izvor: Izračun autorica}

Procjena modela za Hrvatsku iskorištena je u svrhu izrade indeksa cijena stanova. Indeks je izračunat primjenom time-dummy metode (vidjeti Kunovac i sur. (2008); Hill (2011); Slišković i Sekur (2020)). Svrha izrade indeksa bilo je svojevrsno ispitivanje kvalitete podataka iz baze Burze nekretnina. Naime, izrađeni indeks uspoređen je $\mathrm{s}$ indeksom cijena stambenih nekretnina (DZS i HNB) koji je trenutno najrelevantniji pokazatelj trendova na stambenom tržištu u Hrvatskoj, a izrađen je na temelju podataka o kupoprodajama koje dostavlja Porezna uprava. Na Slici 2. ilustrirana su kretanja indeksa cijena stambenih 
nekretnina i indeksa cijena izračunatih na temelju modela 2 traženih cijena (Tablica 5.).

Prikazana slika navodi na dva značajna zaključka. Prvo, razvidno je da razlike u pojedinim godinama postoje, a to je primarno rezultat kvalitete podataka na temelju kojih su indeksi izračunati. Naime, pri izračunu novog indeksa u pojedinim godinama bilo je zabilježeno relativno malo promatranja, što rezultira odstupanjima od kretanja ICSN-a koji se temelji na sveobuhvatnoj bazi transakcija. No, usprkos tome, može se jasno vidjeti kako je trend kretanja cijena mjeren novim indeksom vrlo sličan trendu ICSN-a. Stoga se može zaključiti kako je i baza podataka na kojoj se ovo istraživanje temelji zadovoljavajuća i kako su zaključci koji proizlaze iz analize tih podataka primjereni. Drugi je zaključak taj da, usprkos svim događajima koji su u negativnom kontekstu obilježili 2020., ipak postoji stabilan rast cijena stanova na hrvatskom tržištu koji se nastavlja na pozitivna kretanja iz prethodnih godina. Detaljniju sliku o potencijalnom učinku subvencija na stambene kredite i prošlogodišnjih neočekivanih šokova dat će procjene modela za pojedina tržišta koje su provedene u drugoj fazi istraživanja.

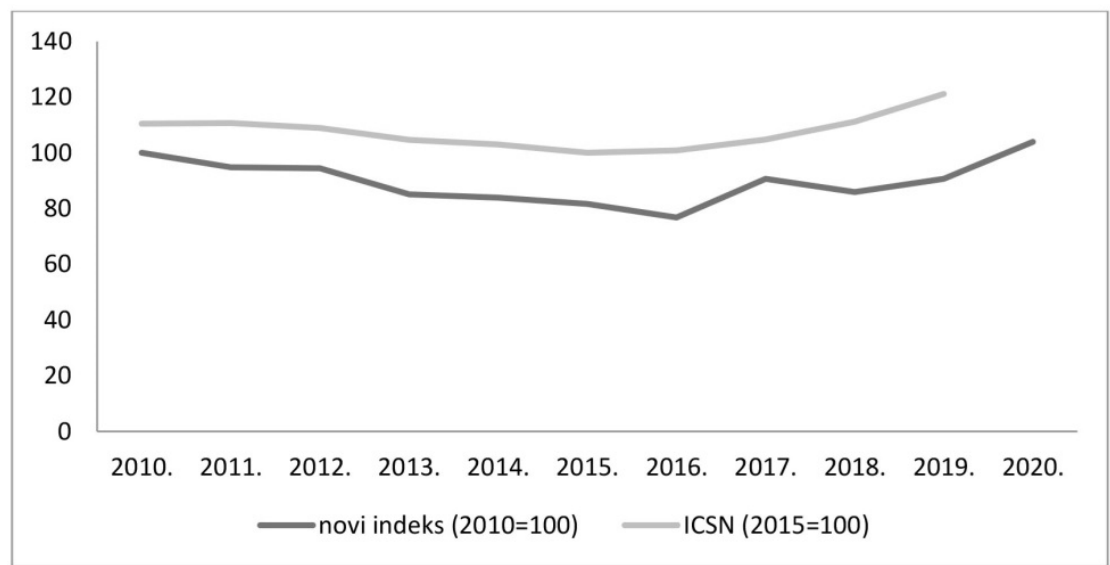

Slika 2. Novoizračunati indeks cijena stanova i indeks cijena stambenih nekretnina za Hrvatsku (2010. - 2020.)

Izvor: Izračun autorica; $H N B$ (2021)

Modeli procjene za tržište regije Jadran predstavljeni su u Tablici 6 . Ovdje je povezanost standardnih varijabli (tzv. minimalnog skupa varijabli) s postignutim i traženim cijenama kvadratnog metra stana potvrđena s obzirom na to da su gotovo svi parametri, osim onoga uz varijablu sobe, statistički značajni. Tako je i ovom slučaju razvidno kako se cijene stanova u prosjeku statistički značajno razlikuju prema lokacijama, odnosno u različitim županijama cijene su statistički značajno različite od prosječnih cijena u županiji koja je obuhvaćena konstantnim članom regresije (Splitsko-dalmatinska). Pri tome su cijene statistički značajno više jedino u Dubrovačko-neretvanskoj županiji. Dinamika 
cijena u vremenskoj dimenziji pokazuje kako cijene u 2020. nisu statistički značajno različite od godine obuhvaćene konstantnim članom (2010.). Drugim riječima, ovo se može interpretirati tako da su cijene u 2020. došle na razinu iz 2010., no kako su u svim ostalim godinama cijene statistički značajno u prosjeku manje u odnosu na 2010., zaključuje se kako su cijene stanova u 2020. porasle u odnosu na prethodna razdoblja.

Tablica 6.

Rezultati procijenjenog hedoničkog modela za regiju Jadran

\begin{tabular}{|c|c|c|c|c|c|c|c|c|}
\hline \multirow{2}{*}{$\begin{array}{l}\text { Varijabla } \\
\downarrow \\
\text { Model } \rightarrow\end{array}$} & \multicolumn{4}{|c|}{$\begin{array}{c}\text { Zavisna varijabla: } \log (\mathrm{P} 1) \text { (logaritam } \\
\text { tražene cijene) }\end{array}$} & \multicolumn{4}{|c|}{$\begin{array}{c}\text { Zavisna varijabla: } \log (\mathrm{P} 2) \text { (logaritam } \\
\text { postignute cijene) }\end{array}$} \\
\hline & 1 & 2 & 3 & 4 & 1a & $2 \mathrm{a}$ & $3 a$ & $4 a$ \\
\hline C & $7,80 * * *$ & $7,80 * * *$ & $7,80 * * *$ & $7,80 * * *$ & $7,78 * * *$ & $7,77 * * *$ & $7,77 * * *$ & $7,77 * * *$ \\
\hline DUBNER & $0,12^{* * *}$ & $0,12 * * *$ & $0,12^{* * *}$ & $0,12 * * *$ & $0,12 * * *$ & $0,12 * * *$ & $0,12 * * *$ & $0,12 * * *$ \\
\hline SIBKNIN & $-0,30 * * *$ & $-0,29 * * *$ & $-0,29 * * *$ & $-0,29 * * *$ & $-0,32 * * *$ & $-0,32 * * *$ & $-0,32 * * *$ & $-0,32 * * *$ \\
\hline ZAD & $-0,23 * * *$ & $-0,23 * * *$ & $-0,23 * * *$ & $-0,23 * * *$ & $-0,29 * * *$ & $-0,29 * * *$ & $-0,30 * * *$ & $-0,29 * * *$ \\
\hline IST & $-0,23 * * *$ & $-0,22 * * *$ & $-0,22 * * *$ & $-0,22 * * *$ & $-0,23 * * *$ & $-0,23 * * *$ & $-0,23 * * *$ & $-0,23 * * *$ \\
\hline LICSENJ & $-0,64 * * *$ & $-0,63 * * *$ & $-0,64 * * *$ & $-0,63 * * *$ & $-0,67 * * *$ & $-0,66 * * *$ & $-0,67 * * *$ & $-0,66 * * *$ \\
\hline PRIMGOR & $-0,35 * * *$ & $-0,34 * * *$ & $-0,35 * * *$ & $-0,35^{* * *}$ & $-0,38 * * *$ & $-0,38 * * *$ & $-0,38 * * *$ & $-0,38 * * *$ \\
\hline M2 & $0,00 * * *$ & $0,00 * * *$ & $0,00 * * *$ & $0,00 * * *$ & $0,00^{* * *}$ & $0,00 * * *$ & $0,00 * * *$ & $0,00 * * *$ \\
\hline SOBE & 0,01 & 0,01 & 0,01 & 0,01 & 0,00 & 0,00 & 0,00 & 0,00 \\
\hline NOVOGRADNJA & $0,17 * * *$ & $0,18 * * *$ & $0,17 * * *$ & $0,17 * * *$ & $0,17 * * *$ & $0,18 * * *$ & $0,18 * * *$ & $0,18 * * *$ \\
\hline Y2011 & $-0,09 * *$ & $-0,08 * *$ & $-0,09 * *$ & $-0,09 * *$ & $-0,05^{*}$ & $-0,05$ & $-0,05^{*}$ & $-0,05^{*}$ \\
\hline Y2012 & $-0,17 * * *$ & $-0,16^{* * *}$ & $-0,17 * * *$ & $-0,16^{* * *}$ & $-0,21 * * *$ & $-0,21 * * *$ & $-0,21 * * *$ & $-0,21 * * *$ \\
\hline Y2013 & $-0,27 * * *$ & $-0,27 * * *$ & $-0,27 * * *$ & $-0,27 * * *$ & $-0,30 * * *$ & $-0,30 * * *$ & $-0,30 * * *$ & $-0,30 * * *$ \\
\hline Y2014 & $-0,19 * * *$ & $-0,19 * * *$ & $-0,19 * * *$ & $-0,19 * * *$ & $-0,22 * * *$ & $-0,21 * * *$ & $-0,22 * * *$ & $-0,21 * * *$ \\
\hline Y2015 & $-0,28 * * *$ & $-0,28 * * *$ & $-0,28 * * *$ & $-0,28 * * *$ & $-0,28 * * *$ & $-0,28 * * *$ & $-0,28 * * *$ & $-0,28 * * *$ \\
\hline Y2016 & $-0,21 * * *$ & $-0,21 * * *$ & $-0,21 * * *$ & $-0,21 * * *$ & $-0,20 * * *$ & $-0,20 * * *$ & $-0,20 * * *$ & $-0,20 * * *$ \\
\hline Y2017 & $-0,13 * * *$ & $-0,13 * * *$ & $-0,13 * * *$ & $-0,13 * * *$ & $-0,09 * *$ & $-0,09 * *$ & $-0,09 * *$ & $-0,09 * *$ \\
\hline Y2018 & $-0,35 * * *$ & $-0,34 * * *$ & $-0,35 * * *$ & $-0,34 * * *$ & $-0,29 * *$ & $-0,28 * *$ & $-0,29 * *$ & $-0,28 * *$ \\
\hline Y2019 & $-0,51 * * *$ & $-0,50 * * *$ & $-0,52 * * *$ & $-0,50 * * *$ & $-0,48 * * *$ & $-0,47 * * *$ & $-0,48 * * *$ & $-0,47 * * *$ \\
\hline Y2020 & 0,06 & 0,02 & 0,00 & $0,09^{*}$ & 0,04 & 0,03 & 0,01 & 0,06 \\
\hline COVID & $-0,07$ & - & - & $-0,08^{*}$ & $-0,03$ & - & - & $-0,04$ \\
\hline APN & 0,05 & - & $0,06^{*}$ & - & 0,04 & - & 0,05 & - \\
\hline ADJ $R^{2}$ & 0,31 & 0,31 & 0,31 & 0,31 & 0,21 & 0,21 & 0,21 & 0,21 \\
\hline
\end{tabular}

Napomena: Zvjezdice ukazuju na odbacivanje nulte hipoteze o neznačajnosti procijenjenog parametra $(\beta=0)$ na razinama statističke signifikantnosti od $1 \%(* * *), 5 \%(* *)$ i $10 \%(*)$.

Izvor: Izračun autorica 
Regija Jadran jedini je segment tržišta unutar kojeg je potvrđena statistički značajna negativna povezanost pandemije koronavirusa i cijena stanova. No, vidljivo je kako je parametar uz varijablu COVID statistički značajan jedino u modelu gdje je zavisna varijabla tražena cijena. Slijedom toga, moglo bi se ocijeniti kako je razdoblje pandemije utjecalo na očekivanja prodavatelja stanova koji su zbog nesigurnosti smanjili svoja očekivanja. Prema rezultatima, ako su stanovi prodani u razdoblju pandemije, njihova je tražena cijena $\mathrm{u}$ prosjeku bila manja za $8 \%$ u odnosu na razdoblje prodaje prije pandemije. Također, treba naglasiti kako ovaj rezultat, iako u skladu s početnim očekivanjima, nije robustan. Što se tiče učinka subvencija, ako se promatra njihov izoliran učinak (bez uključivanja šoka pandemije), rezultati pokazuju kako je u razdobljima trajanja natječaja za subvencije (i u mjesecu prije natječaja) tražena cijena stanova u prosjeku bila viša za $6 \%$. S druge strane, statistička značajnost ove varijable nije pronađena u modelima postignutih cijena, što upućuje na zaključak da su subvencije potaknule optimizam prodavatelja koji su za svoje stanove tražili više cijene. U modelima postignutih cijena varijabla APN nije statistički značajna pa se može postaviti pitanje u kojoj su mjeri povećani zahtjevi prodavatelja doista i realizirani.

Procjena modela u regiji Ostalo (Tablica 7.) rezultirala je jasnim i nedvosmislenim zaključcima koji se u potpunosti poklapaju s početnim očekivanjima i stanjem tržišta na ovom segmentu. Naime, regija Ostalo dio je Hrvatske $u$ kojem je realiziran najmanji broj transakcija. S obzirom na činjenicu da je tržište stanova na ovom segmentu značajno manje aktivno nego u preostalim dvjema regijama, činila se logičnom pretpostavka da će biti aktivniji oni dijelovi tržišta koji su locirani bliže najfrekventnijem tržištu (Zagreb). To se može zaključiti iz dobivenih rezultata, prema kojima su cijene stanova u Zagrebačkoj i Karlovačkoj županiji statistički značajno u prosjeku više od cijena stanova koji su locirani u Bjelovarsko-bilogorskoj županiji (stalan član regresije), dok statistički značajna razlika u cijenama u odnosu na baznu županiju nije pronađena u ostalim županijama ove regije. Parametri uz varijable kojima se opisuje vremenska dimenzija ukazuju na zaključak kako se cijene u većini godina nisu statistički značajno mijenjale u odnosu na 2010., što potvrđuje pretpostavku da je stambeno tržište u ovom dijelu Hrvatske prilično uspavano. 
Tablica 7.

Rezultati procijenjenog hedoničkog modela za regiju Ostalo

\begin{tabular}{|c|c|c|c|c|c|c|c|c|c|c|}
\hline \multirow{2}{*}{$\begin{array}{l}\text { Varijabla } \\
\downarrow \\
\text { Model } \rightarrow\end{array}$} & \multicolumn{5}{|c|}{$\begin{array}{c}\text { Zavisna varijabla: } \log (\mathrm{P} 1)(\text { logaritam } \\
\text { tražene cijene) }\end{array}$} & \multicolumn{5}{|c|}{$\begin{array}{c}\text { Zavisna varijabla: } \log (\mathrm{P} 2)(\operatorname{logaritam} \\
\text { postignute cijene) }\end{array}$} \\
\hline & 1 & 2 & 3 & 4 & 5 & la & $2 \mathrm{a}$ & $3 a$ & $4 a$ & $5 a$ \\
\hline C & $6,88^{* * *}$ & $6,87 * * *$ & $6,88^{* * *}$ & $6,87^{* * *}$ & $6,88 * * *$ & 6,81 *** & $6,81 * * *$ & $6,81 * * *$ & $6,81 * * *$ & $6,81 * * *$ \\
\hline KRAZAG & 0,06 & 0,06 & 0,06 & 0,06 & 0,06 & 0,06 & 0,06 & 0,06 & 0,06 & 0,07 \\
\hline KARL & $0,14 * *$ & $0,14 * *$ & $0,14 * *$ & $0,14 * *$ & $0,13 * *$ & $0,12 * *$ & $0,11 *$ & $0,12 * *$ & $0,12 *$ & $0,11^{*}$ \\
\hline OSBAR & $-0,01$ & 0,00 & $-0,01$ & 0,00 & $-0,02$ & 0,02 & 0,03 & 0,02 & 0,03 & 0,01 \\
\hline VAR & 0,07 & 0,07 & 0,07 & 0,07 & 0,07 & 0,06 & 0,06 & 0,06 & 0,06 & 0,06 \\
\hline ZAGR & $0,15^{* * *}$ & $0,15^{* * *}$ & $0,15^{* * *}$ & $0,15^{* * *}$ & $0,16^{* * *}$ & 0,19 *** & $0,19 * * *$ & 0,19 *** & $0,19 * * *$ & $0,20 * * *$ \\
\hline M2 & $0,00 * * *$ & $0,00 * * *$ & $0,00 * * *$ & $0,00^{* * *}$ & $0,00 * * *$ & $0,00^{* * *}$ & $0,00 * * *$ & $0,00^{* * *}$ & $0,00 * * *$ & $0,00 * * *$ \\
\hline SOBE & $-0,01$ & 0,00 & $-0,01$ & 0,00 & $-0,01$ & $-0,01$ & $-0,01$ & $-0,01$ & $-0,01$ & $-0,01$ \\
\hline NOVOGRADNJA & $0,17 * * *$ & $0,18^{* * *}$ & $0,17 * * *$ & $0,18 * * *$ & $0,17 * * *$ & $0,22 * * *$ & $0,22 * * *$ & $0,22 * * *$ & $0,22 * * *$ & $0,21 * * *$ \\
\hline Y2011 & $-0,05$ & $-0,05$ & $-0,05$ & $-0,05$ & $-0,05$ & $-0,06$ & $-0,06$ & $-0,06$ & $-0,06$ & $-0,05$ \\
\hline Y2012 & $-0,02$ & $-0,02$ & $-0,02$ & $-0,02$ & $-0,02$ & 0,00 & 0,00 & 0,00 & 0,00 & 0,00 \\
\hline Y2013 & $-0,14 *$ & $-0,14 *$ & $-0,14 *$ & $-0,14 *$ & $-0,14 *$ & $-0,18 * *$ & $-0,18 * *$ & $-0,18 * *$ & $-0,18 * *$ & $-0,18 * *$ \\
\hline Y2014 & $-0,09$ & $-0,09$ & $-0,09$ & $-0,09$ & $-0,09$ & $-0,16 * * *$ & $\begin{array}{c}- \\
0,16^{* * * *}\end{array}$ & $-0,16^{* * *}$ & $0,16 * * *$ & $-0,16 * * *$ \\
\hline Y2015 & $-0,12 *$ & $-0,12 *$ & $-0,12 *$ & $-0,12 *$ & $-0,12 *$ & $-0,17 * *$ & $-0,17 * *$ & $-0,17 * *$ & $-0,17 * *$ & $-0,17 * *$ \\
\hline Y2016 & $-0,13 * *$ & $-0,13 * *$ & $-0,13 * *$ & $-0,13 * *$ & $-0,13 * *$ & $-0,15^{* *}$ & $-0,15^{* *}$ & $-0,15^{* *}$ & $-0,15^{* *}$ & $-0,15^{* *}$ \\
\hline Y2017 & $-0,11$ & $-0,11$ & $-0,11$ & $-0,11$ & $-0,11$ & $-0,10$ & $-0,10$ & $-0,10$ & $-0,10$ & $-0,10$ \\
\hline Y2018 & $-0,09$ & $-0,09$ & $-0,09$ & $-0,09$ & $-0,09$ & $-0,01$ & $-0,01$ & $-0,01$ & $-0,01$ & $-0,01$ \\
\hline Y2019 & $-0,11 *$ & $-0,06$ & $-0,11^{*}$ & $-0,06$ & $-0,11 *$ & $-0,16 * * *$ & $-0,11 * *$ & $-0,16 * * *$ & $-0,11 * *$ & $-0,16 * * *$ \\
\hline Y2020 & $0,15^{*}$ & $0,22 * * *$ & $0,17 * *$ & $0,23 * * *$ & $0,15^{*}$ & 0,12 & $0,16 * * *$ & $0,11 *$ & $0,19 * * *$ & 0,11 \\
\hline COVID & 0,02 & - & - & $-0,01$ & 0,03 & 0,00 & - & - & $-0,03$ & 0,02 \\
\hline APN & $0,11 * *$ & - & $0,10 * *$ & - & $0,11 * *$ & $0,10 * *$ & - & $0,10^{* *}$ & - & $0,10^{* *}$ \\
\hline POTRES*ZAGR & - & - & - & - & $-0,04$ & - & - & - & - & $-0,07$ \\
\hline ADJ $R^{2}$ & 0,33 & 0,32 & 0,33 & 0,32 & 0,33 & 0,31 & 0,31 & 0,31 & 0,31 & 0,31 \\
\hline
\end{tabular}

Napomena: Zvjezdice ukazuju na odbacivanje nulte hipoteze o neznačajnosti procijenjenog parametra $(\beta=0)$ na razinama statističke signifikantnosti od $1 \%(* * *), 5 \%(* *)$ i $10 \%(*)$.

\section{Izvor: Izračun autorica}

Procijenjeni modeli ukazuju na jednoznačan zaključak o pozitivnom učinku mjere subvencioniranja stambenih kredita na cijene stanova u regiji Ostalo. Iz procijenjenih parametara (Tablica 7.) može se oblikovati zaključak kako su subvencije na stambene kredite doista jednim dijelom potaknule potražnju za stanovima, a rezultat subvencija očituje se u statistički značajno višim traženim $i$ postignutim cijenama stanova $u$ razdobljima natječaja $i$ neposredno prije. Učinak subvencija je, prema procjeni, pozitivan te one 
rezultiraju u prosjeku 10 - 11\% višim cijenama stanova. Na primjeru stambenog tržišta u regiji Ostalo nije potvrđena statistička značajna povezanost pandemije s cijenama stanova. Dodatno, uključena je varijabla kojom se nastojao procijeniti učinak potresa u Zagrebu na cijene stanova lociranih u susjednoj, Zagrebačkoj županiji, no ona nije statistički značajna.

Jasnu ocjenu o značajnosti lokacije daju i procjene modela zagrebačkog tržišta (Tablica 8.). Rezultati pokazuju kako su cijene kvadratnog metra stanova na zagrebačkom tržištu u prosjeku najviše u centru grada. Modalitet kojim je opisana lokacija stana u centru i Donjem gradu obuhvaćen je stalnim članom regresije, a parametri uz gotovo sve lokacijske varijable negativni su i statistički značajni. Prema tome, cijene kvadratnog metra su, na drugim lokacijama, statistički značajno različite od onih u centru grada i u prosjeku niže. Izuzetak su kvartovi Gornji grad i Medveščak (DMEDVESCAK), gdje su tražene cijene značajno različite $\mathrm{i}$ više, ali postignute cijene nisu statistički značajno različite $u$ odnosu na prosječne cijene u centru grada. Interpretacija parametara uz varijable godina prodaje ukazuju na to da je u 2020. prisutan porast cijena i na ovom segmentu nacionalnog tržišta.

Posebno zanimljivi rezultati vežu se uz učinke potresa. Naime, usporedno s rezultatom da su prosječne cijene kvadratnog metra u centru općenito više nego na drugim lokacijama, stoji i činjenica kako je centar Zagreba najsnažnije pogođen potresom iz ožujka. Većina je zgrada u jezgri grada stara pa su se posljedice potresa najviše odrazile na njima. Iz tog je razloga najprije procijenjen sveukupan učinak potresa na cijene stanova u Zagrebu (model 3 i 3a), a potom je procijenjen učinak na pojedine segmente stambenog fonda, prema starosti zgrada (model 4 i 4 a). 
Tablica 8 .

Rezultati procijenjenog hedoničkog modela za Grad Zagreb

\begin{tabular}{|c|c|c|c|c|c|c|c|c|}
\hline \multirow{2}{*}{$\begin{array}{l}\text { Varijabla } \\
\downarrow \\
\text { Model } \rightarrow\end{array}$} & \multicolumn{4}{|c|}{$\begin{array}{c}\text { Zavisna varijabla: } \log (\mathrm{P} 1) \\
\text { (logaritam tražene cijene) }\end{array}$} & \multicolumn{4}{|c|}{$\begin{array}{c}\text { Zavisna varijabla: log (P2) (logaritam } \\
\text { postignute cijene) }\end{array}$} \\
\hline & 1 & 2 & 3 & 4 & 1a & $2 \mathrm{a}$ & $3 a$ & $4 a$ \\
\hline C & $7,76^{* * *}$ & $7,76 * * *$ & $7,75^{* * *}$ & $7,78 * * *$ & $7,66 * * *$ & $7,66 * * *$ & $7,66 * * *$ & $7,69 * * *$ \\
\hline DMAKSIMIR & $-0,14 * * *$ & $-0,14 * * *$ & $-0,14 * * *$ & $-0,15 * * *$ & $-0,17 * * *$ & $-0,17 * * *$ & $-0,17 * * *$ & $-0,20 * * *$ \\
\hline DNZISTOK & $-0,42 * * *$ & $-0,42 * * *$ & $-0,42 * * *$ & $-0,43 * * *$ & $-0,40 * * *$ & $-0,40 * * *$ & $-0,40 * * *$ & $-0,42 * * *$ \\
\hline DNZZAPAD & $-0,33 * * *$ & $-0,33 * * *$ & $-0,33 * * *$ & $-0,34 * * *$ & $-0,36 * * *$ & $-0,36 * * *$ & $-0,36^{* * *}$ & $-0,38 * * *$ \\
\hline DPESCENICA & $-0,25 * * *$ & $-0,25 * * *$ & $-0,25 * * *$ & $-0,27 * * *$ & $-0,25 * * *$ & $-0,24 * * *$ & $-0,25 * * *$ & $-0,27 * * *$ \\
\hline DMEDVESCAK & $0,04 *$ & $0,04 *$ & $0,04 *$ & $0,05 * *$ & 0,00 & 0,00 & 0,00 & 0,00 \\
\hline DZAPAD & $-0,37 * * *$ & $-0,37 * * *$ & $-0,37 * * *$ & $-0,39 * * *$ & $-0,36 * * *$ & $-0,36 * * *$ & $-0,36 * * *$ & $-0,39 * * *$ \\
\hline DPODSLJEME & $-0,20 * * *$ & $-0,20 * * *$ & $-0,19 * * *$ & $-0,21 * * *$ & $-0,23 * * *$ & $-0,23 * * *$ & $-0,23 * * *$ & $-0,26 * * *$ \\
\hline DTRESNJEVKASJEVER & $-0,24 * * *$ & $-0,24 * * *$ & $-0,24 * * *$ & $-0,26 * * *$ & $-0,22 * * *$ & $-0,22 * * *$ & $-0,22 * * *$ & $-0,25 * * *$ \\
\hline DTRNJE & $-0,16^{* * *}$ & $-0,16^{* * *}$ & $-0,16 * * *$ & $-0,16^{* * *}$ & $-0,15^{* * *}$ & $-0,15^{* * *}$ & $-0,15^{* * *}$ & $-0,16^{* * *}$ \\
\hline DDUBRAVA & $-0,39 * * *$ & $-0,39 * * *$ & $-0,39 * * *$ & $-0,41 * * *$ & $-0,37 * * *$ & $-0,37 * * *$ & $-0,38 * * *$ & $-0,40 * * *$ \\
\hline DTRESNJEVKAJUG & $-0,25 * * *$ & $-0,25 * * *$ & $-0,25 * * *$ & $-0,26 * * *$ & $-0,21 * * *$ & $-0,21 * * *$ & $-0,22 * * *$ & $-0,23 * * *$ \\
\hline DCRNOMEREC & $-0,21 * * *$ & $-0,21 * * *$ & $-0,21 * * *$ & $-0,22 * * *$ & $-0,21 * * *$ & $-0,21 * * *$ & $-0,21 * * *$ & $-0,23 * * *$ \\
\hline DOSTALO & $-0,61 * * *$ & $-0,61 * * *$ & $-0,61 * * *$ & $-0,63 * * *$ & $-0,60 * * *$ & $-0,60 * * *$ & $-0,60 * * *$ & $-0,64 * * *$ \\
\hline M2 & $0,00^{* *}$ & $0,00 * *$ & $0,00^{* *}$ & $0,00 * * *$ & $0,00 * * *$ & $0,00 * * *$ & $0,00 * * *$ & $0,00 * * *$ \\
\hline SOBE & 0,00 & 0,00 & 0,00 & 0,00 & 0,00 & 0,00 & 0,00 & 0,00 \\
\hline NOVOGRADNJA & $0,08 * * *$ & $0,08 * * *$ & $0,08 * * *$ & $0,07 * * *$ & $0,11 * * *$ & $0,11 * * *$ & $0,11 * * *$ & $0,10 * * *$ \\
\hline Y2011 & $-0,06 * * *$ & $-0,06 * * *$ & $-0,06 * * *$ & $-0,06 * * *$ & $-0,07 * * *$ & $-0,07 * * *$ & $-0,07 * * *$ & $-0,06 * * *$ \\
\hline Y2012 & $-0,08 * * *$ & $-0,08 * * *$ & $-0,08 * * *$ & $-0,08 * * *$ & $-0,07 * * *$ & $-0,07 * * *$ & $-0,07 * * *$ & $-0,07 * * *$ \\
\hline Y2013 & $-0,18 * * *$ & $-0,18^{* * * *}$ & $-0,18 * * *$ & $-0,19 * * *$ & $-0,20 * * *$ & $-0,20 * * *$ & $-0,20 * * *$ & $-0,22 * * *$ \\
\hline Y2014 & $-0,23 * * *$ & $-0,23 * * *$ & $-0,23 * * *$ & $-0,23 * * *$ & $-0,21 * * *$ & $-0,21 * * *$ & $-0,21 * * *$ & $-0,21 * * *$ \\
\hline Y2015 & $-0,25 * * *$ & $-0,25 * * *$ & $-0,25 * * *$ & $-0,24 * * *$ & $-0,21 * * *$ & $-0,21$ *** & $-0,21 * * *$ & $-0,20 * * *$ \\
\hline Y2016 & $-0,30$ *** & $-0,30 * * *$ & $-0,30 * * *$ & $-0,28 * * *$ & $-0,23 * * *$ & $-0,23 * * *$ & $-0,23 * * *$ & $-0,22 * * *$ \\
\hline Y2017 & $-0,22 * * *$ & $-0,22 * * *$ & $-0,22 * * *$ & $-0,24 * * *$ & $-0,13 * * *$ & $-0,13 * * *$ & $-0,13 * * *$ & $-0,15^{* * *}$ \\
\hline Y2018 & $-0,13 * * *$ & $-0,13 * * *$ & $-0,13 * * *$ & $-0,10 * * *$ & $-0,06^{*}$ & $-0,06^{*}$ & $-0,06^{*}$ & $-0,04$ \\
\hline Y2019 & $-0,03$ & $-0,03$ & $-0,03$ & $-0,02$ & 0,04 & 0,03 & 0,03 & 0,04 \\
\hline Y2020 & $0,04 * *$ & $0,04 * * *$ & 0,02 & 0,01 & $0,03 *$ & $0,05 * * *$ & 0,01 & 0,01 \\
\hline COVID & 0,01 & - & - & - & $0,04 * * *$ & - & - & - \\
\hline APN & $-0,01$ & - & 0,00 & 0,00 & $-0,01$ & - & 0,00 & 0,01 \\
\hline POTRES & - & - & $0,04 * *$ & - & - & - & $0,06 * * *$ & - \\
\hline POTRES*NOVIJA & - & - & - & $0,07 * * *$ & - & - & - & $0,11 * * *$ \\
\hline POTRES*STARIJA & - & - & - & 0,02 & - & - & - & $0,04 * *$ \\
\hline POTRES*NAJSTARIJA & - & - & - & 0,01 & - & - & - & 0,01 \\
\hline ADJ $\mathbf{R}^{2}$ & 0,42 & 0,42 & 0,43 & 0,44 & 0,41 & 0,41 & 0,41 & 0,44 \\
\hline
\end{tabular}

Napomena: Zvjezdice ukazuju na odbacivanje nulte hipoteze o neznačajnosti procijenjenog parametra $(\beta=0)$ na razinama statističke signifikantnosti od $1 \%(* * *), 5 \%(* *)$ i $10 \%(*)$.

Izvor: Izračun autorica 
Procjena učinka potresa na cijene svih stanova u Zagrebu rezultirala je na prvi pogled nelogičnim rezultatom. Iz modela 3 i 3a moguće je iščitati kako je parametar uz varijablu potres statistički značajan i pozitivan. Taj neočekivani rezultat potom se rasvijetlio promatranjem učinaka potresa na zgrade različite starosti. U modelima 4 i $4 \mathrm{a}$ u Tablici 8. razdvojen je utjecaj potresa na zgrade novije, starije i najstarije gradnje. Prema Atalić, Uroš i Šavor Novak (2019), zgrade izgrađene do 1945. imaju inicijalnu, od 1946. do 1964. minimalnu, od 1965. do 1981. nisku, od 1982. do 1998. srednju, a zgrade izgrađene nakon 1999. visoku razinu potresne otpornosti. U skladu s navedenim uzorak je podijeljen na stanove novije izgradnje (izgrađeni nakon 1999.), starije izgradnje (izgrađeni nakon 1982.), a stanovi inicijalne, minimalne i niske potresne otpornosti svrstani su u stanove najstarije izgradnje (izgrađeni do 1981.). Ovakva podjela daje bolji uvid $\mathrm{u}$ izvore pozitivnog utjecaja potresa na cijene stanova. Rezultati su rasvijetlili činjenicu da je potres zapravo imao učinke u smislu porasta cijena u segmentu stanova novije gradnje, što se može objasniti činjenicom kako je nakon potresa porasla potražnja za stanovima novije gradnje, koji su građeni prema boljim standardima gradnje i otporniji na potrese. Usprkos očekivanju da će se učinci potresa u segmentu najstarijih zgrada očitovati u prosječno nižim cijenama stanova u takvim zgradama u razdoblju nakon potresa, nisu pronađeni dokazi koji na to ukazuju (koeficijenti uz varijablu potres*najstarija nisu statistički značajni).

Što se tiče učinaka mjere subvencioniranja stambenih kredita, rezultati pokazuju kako ta mjera nije statistički značajna u objašnjavanju traženih i postignutih cijena na tržištu Grada Zagreba. Iz rezultata moguće je iščitati i kako je parametar uz varijablu COVID pozitivan i statistički značajan u modelu procjene postignutih cijena. No, kako u tom modelu (1a, Tablica 8.) nije istovremeno obuhvaćen učinak potresa ${ }^{2}$, vjerojatno je kako taj, neočekivan rezultat proizlazi iz već objašnjenog porasta cijena novije gradnje, koji je povezan s potresom, no u konkretnom modelu nije uključen u skup nezavisnih varijabli.

\section{ZAKLJUČAK}

Procjena niza hedoničkih modela traženih i postignutih cijena stanova na nacionalnom, ali i na geografski užim tržištima rezultirala je prilično jednoznačnim zaključcima koji se mogu sažeti u tvrdnjama koje slijede. Prvo, razvidno je kako je, usprkos svim nedaćama koje su zahvatile hrvatsko gospodarstvo, u 2020. nastavljen rast cijena stanova na nacionalnom, ali i na većini regionalnih tržišta. Prema relevantnim pokazateljima cijena stambenog prostora, rast cijena stanova postojan je u razdoblju od 2015. do 2019. te je, po svemu sudeći, nastavljen i u 2020. Pokazalo se da je većina varijabli iz tzv. minimalnog skupa obilježja statistički značajna za objašnjavanje postignutih i

\footnotetext{
${ }^{2}$ Varijabla COVID označava vrijeme prodaje stana od početka ožujka 2020. nadalje, dok varijabla POTRES označava da je stan prodan u razdoblju nakon potresa (22. 3. 2020.). Slijedom toga, ove dvije varijable obuhvaćaju vrlo slično vremensko razdoblje te ih se, zbog visoke koreliranosti, nije moglo procjenjivati zajedno u istom modelu.
} 
traženih cijena stanova, pri čemu se posebno ističe varijabla lokacije. U središtu je interesa, pak, bila procjena učinaka šokova pandemije koronavirusa i zagrebačkog potresa na cijene stanova. U procjenama nacionalnog, ali i modela za tri zasebne regije koje čine smislene cjeline, nisu pronađeni dokazi koji bi mogli upućivati na to da su pandemija bolesti covid-19 i mjere koje se provode od ožujka značajnije poljuljale stabilan trend porasta cijena stanova. No, ovdje je važno naglasiti kako taj rezultat treba razmatrati s oprezom. Naime, moguće je da je pandemija rezultirala smanjenjem broja ukupnih transakcija. Baza podataka Burze nekretnina, kako je u radu naglašeno, nema podatke o svim realiziranim transakcijama, već samo o određenom broju njih. S tim u skladu, za potrebe ovog istraživanja nije bio dostupan podatak o ukupnom broju transakcija koje su realizirane u Hrvatskoj i na pojedinim tržištima koja se u radu analiziraju. Taj bi podatak zasigurno omogućio sagledavanje učinaka pandemije koronavirusa na tržište stanova u drugom svjetlu. Ako se promatra samo učinak pandemije na cijene (ali ne i na obujam transakcija), tada su moguća dva objašnjenja za činjenicu da je njihov rast nastavljen i u uvjetima pandemije te zaključavanja gospodarstva. Prvo, moguće je da su subjekti na tržištu percipirali pandemiju kao kratkoročno stanje, koje nije utjecalo na donošenje odluke o kupnji nekretnine na strani potražnje. Dugoročnije promjene, koje bi u prvom redu poremetile platežnu i kreditnu sposobnost subjekata na strani potražnje, vjerojatno bi utjecale na potražnju pa samim time, s vremenskim odmakom, i na cijene na tržištu. Sukladno s time, ako pandemija prouzroči dugoročnije promjene u gospodarstvu, ti bi se učinci mogli preliti na tržište stanova i odraziti na njihove cijene. Drugo, nastavak rasta cijena u 2020. moguće je sagledati i na temelju događanja na strani ponude koja nisu obuhvaćena ovim istraživanjem. Naime, poremećaji u lancima nabave doveli su do porasta cijena građevinskog materijala, što je povećalo troškove izgradnje, a tim dovelo i do porasta cijena novoizgrađenih kvadrata na tržištu. Ovo svakako predstavlja iznimno značajno istraživačko pitanje, kojem je potrebno pridati pozornost u budućim istraživanjima ove problematike.

Što se tiče učinaka potresa na cijene stanova na zagrebačkom tržištu, izgledno je da su se oni očitovali u porastu cijena stanova koji se nalaze $u$ zgradama novije gradnje koje su otpornije na potrese. Suprotno početnim očekivanjima, potres se nije pokazao kao statistički značajan događaj koji je povezan s promjenom cijena stanova u zgradama izgrađenima prije 1981.

Posebno zanimljivi rezultati vežu se uz učinke mjere subvencioniranja stambenih kredita na cijene kvadratnog metra stanova u Hrvatskoj i pojedinim regijama. Provedena analiza ukazuje da su te mjere djelomično imale učinke na pojedinim tržištima. Konkretno, čini se da je mjera subvencioniranja imala pozitivan učinak na tražene cijene u regiji Jadran (ali ne i na postignute), no taj rezultat nije potpuno robustan. S druge strane, potvrdilo se kako je program subvencija povezan s porastom traženih i postignutih cijena na najmanje razvijenom tržištu u Hrvatskoj (regija Ostalo) i taj se rezultat pokazao robusnim.

Iako je većina dobivenih rezultata u skladu s početnim očekivanjima, treba još jednom istaknuti kako glavno ograničenje predstavljaju nedostaci 
korištene baze podataka. Osim već spomenute činjenice kako baza ne obuhvaća sve transakcije na stambenom tržištu, postoje još neke dodatne manjkavosti. Primjerice, kvaliteta i broj prikupljenih evidentiranih podataka poboljšava se $s$ godinama pa tako postoji problem velikih razlika $\mathrm{u}$ distribuciji podataka po pojedinim godinama, što znatno može utjecati na izračun indeksa cijena. Nadalje, relativno skromni korigirani koeficijenti determinacije u pojedinim modelima ukazuju na činjenicu da u modelima postoji prostor za uključivanje dodatnih varijabli kojima bi se mogle objasniti cijene stanova na pojedinim tržištima. Tomu bi zasigurno pridonijele dodatne obavijesti o karakteristikama stanova ili još preciznijim lokacijama. Iako baza podataka za posljednju godinu nudi više informacija o karakteristikama nekretnina, one nisu dostupne za ranije godine. Unapređenje kvalitete podataka u smislu kontinuiranog prikupljanja podataka o više karakteristika stanova bilo bi također korisno s više aspekata i omogućilo bi izradu sveobuhvatnijih modela cijena stanova na pojedinim tržištima.

\section{LITERATURA}

Atalić, J.; Uroš, M.; Šavor Novak, M. (2019). „Potresni rizik Grada Zagreba s osvrtom na građevine kritične infrastrukture“. Zaštita kulturne baštine Grada Zagreba u kriznim uvjetima. Ured za upravljanje u hitnim situacijama (ur.). Zagreb.

Botrić, V.; Kordej De Villa, Ž. (2005). „Determinants of regional housing market in Croatia“". $5^{\text {th }}$ Congress of the European Regional Science Association. Amsterdam.

Court, A. T. (1939). „Hedonic Price Indexes with Automotive Examples“. U: The Dynamics of Automobile Demand, str. 99-117. New York: The General Motors Corporation.

Dumičić, K.; Čeh Časni, A.; Žmuk, B. (2011). „Modeliranje priuštivosti novih stanova u Hrvatskoj metodom višestruke linearne regresije“. Zbornik Ekonomskog fakulteta u Zagrebu, Vol. 9, No. 1, str. 33-49.

Griliches, Z. (1961). „Hedonic Price Indexes for Automobiles: An Econometric of Quality Change“. The Price Statistics of the Federal Goverment, No. 73, str. 173-196.

Hill, R. (2011). „Hedonic Price Indexes for Housing“. OECD Statistics Working Papers, 2011/01. OECD Publishing. Dostupno na: http://dx.doi.org/10.1787/5kghzxpt6g6f-en

HNB (2021). Indeksi cijena stambenih nekretnina (statistika). Dostupno na: https://www.hnb.hr/statistika/statisticki-podaci/odabrane-nefinancijske-statistike/indeksi-cijena

Keskin, B. (2008). „Hedonic Analysis of Price in the Istanbul Housing Market“. International Journal of Strategic Property Management, Vol. 12, str. 125-138. https://doi.org/10.3846/1648-715X.2008.12.125-138

Kunovac, D.; Đozović, E.; Lukinić, G.; Pufnik, A. (2008). „Primjena hedonističke metode za izračunavanje indeksa cijena nekretnina u Hrvatskoj“. Istraživanja, Vol. I, No. 20. Zagreb: Hrvatska narodna banka.

Kunovac, D., Kotarac, K. (2019). „Residential Property Prices in Croatia. The Croatian National Bank Surveys“, No. 37. Dostupno na: https://www.hnb.hr/documents/ 20182/2626448/s-037.pdf/19242b77-77f4-51c9-803d-0ccb387a081d [pristup: 1/3/2021]

Kunovac, D., Kotarac, K. (2020). „Utjecaj pandemije i potresa na tržište nekretnina u Zagrebu u prvoj polovini 2020“. HNBlog. Dostupno na: https://www.hnb.hr/- 
/utjecaj-pandemije-i-potresa-na-trziste-nekretnina-u-zagrebu-u-prvoj-polovini-2020 [pristup: 20/3/2021]

Kunovac, D.; Žilić, I. (2020). „Home sweet home: The effects of housing loan subsidies on the housing market in Croatia“. Croatian National Bank Working Papers W60. Dostupno na: https://www.hnb.hr/documents/20182/3596318/w-060.pdf/955d2e9e76d7-8b3e-3c1a-8a8732ff326e [pristup: 15/3/2021]

Lancaster, K. J. (1966). „A New Approach to Consumer Theory“. Journal of Political Economy, Vol. 74, No. 2, str. 132-157. https://doi.org/10.1086/259131

Lovrinčević, Ž.; Vizek, M. (2008). „Determinante cijena nekretnina u Republici Hrvatskoj i potencijalni učinci liberalizacije tržišta nekretnina“. Ekonomski pregled, Vol. 59, str. 723-740.

McDonald, J. F.; McMillen, D. P. (2007). Urban Economics and Real Estate: Theory and Policy. Oxford: Blackwell Publishing.

Mikulić, J.; Vizek, M.; Stojčić, N.; Payne, J.; Čeh Časni, A.; Barbić, T. (2021). „The effect of tourism activity on housing affordability“. Annals of Tourism Research, Vol. 90 (September). https://doi.org/10.1016/j.annals.2021.103264

Narodne novine (2020). Odluka o mjeri strogog ograničavanja zadržavanja na ulicama i drugim javnim mjestima, 34/2020. Zagreb.

Narodne novine (2020). Odluka o zabrani napuštanja mjesta prebivališta i stalnog boravka u Republici Hrvatskoj, 35/2020. Zagreb.

Ottensmann, J. R.; Payton, S.; Man, J. (2008). „Urban Location and Housing Prices within a Hedonic Model““. The Journal of Regional Analysis and Policy, Vol. 38, No. 1, str. 19-35.

Posedel, P.; Vizek, M. (2009). „House Price Determinants in Transition and EU-15 Countries“. Post-Communist Economies, Vol. 21, No. 3, str. 327-343. https://doi.org/ 10.1080/14631370903090640

Rosen, S. (1974). „Hedonic Prices and Implicit Markets: Product Differentiation in Pure Competition“. The Journal of Political Economy, Vol. 82, No. 1, str. 34-55. https://doi.org/10.1086/260169

Sirmans, G. S.; MacDonald, L.; MacPherson, D. A.; Zietz, E. N. (2006). „The Value of Housing Characteristics: A Meta Analysis“. The Journal of Real Estate Finance and Economics, Vol. 33, str. 215-240. https://doi.org/10.1007/s11146-006-9983-5

Slišković, T. (2018) „Analiza međuovisnosti stambenog tržišta i makroekonomskog sustava u Hrvatskoj“. U: Družić, G.; Družić, I. (ur.) Zbornik radova znanstvenog skupa „Modeli razvoja hrvatskog gospodarstva“, str. 247-280. Zagreb: Hrvatska akademija znanosti i umjetnosti - Ekonomski fakultet Sveučilišta u Zagrebu.

Slišković, T. (2019) „Modelling housing market and housing price dynamics in Croatia“. U: Cermakova, K.; Mozayeni, S.; Hromada, E. (ur.). Proceedings of the $12^{\text {th }}$ Economics \& Finance Conference, Dubrovnik. International Institute of Social and Economic Sciences, Prague, Czech Republic, str. 335-352. https://doi.org/10.20472/EFC.2019.012.023

Slišković, T.; Nakić, M.; Sekur, T. (2019). „The Interdependence of Housing Market and Banking Sector in Croatia“. U: Bilgin, M.; Danis, H.; Demir, E.; Can, U. (ur.). Eurasian Economic Perspectives. Eurasian Studies in Business and Economics, Vol. 10, No. 2, str. 277-288. https://doi.org/10.1007/978-3-030-11833-4_18

Slišković, T., Sekur, T. (2020). „The Calculation of Regional Index of Dwelling Prices in Croatia“. Proceedings of Economics and Finance Conferences, 11413128. 
International Institute of Social and Economic Sciences. Dostupno na: https://doi.org/ 10.20472/EFC.2020.014.013

Tica, J. (2020). „Čimbenici kretanja cijena stambenih nekretnina u Hrvatskoj“. Zbornik Ekonomskog fakulteta u Zagrebu, Vol. 18, No. 2, str. 15-33. https://doi.org/ 10.22598/zefzg.2020.2.15

Yiu, C. Y.; Tam, C. S. (2004). „The estimation of housing price gradients: A comparison of different approaches applied in Hong Kong“. International Conference: Adequate \& Affordable Housing for all. Toronto: Centre for Urban and Community Studies, University of Toronto.

Vizek, M. (2010). „Short-run and Long-run Determinants of House Prices in Eastern and Western European Countries". Privredna kretanja i ekonomska politika, Vol. 125, str. 27-60.

Waugh, F. V. (1928). „Quality Factors Influencing Vegetable Prices“. Journal of Farm Economics, Vol. 10 (April), str. 185-196. https://doi.org/10.2307/1230278

Zietz, J.; Zietz, E. N.; Sirmans, G. S. (2008). „Determinants of House Prices: A Quantile Regression Approach“. Journal of Real Estate Finance and Economics, Vol. 37, No. 4, str. 317-333. https://doi.org/10.1007/s11146-007-9053-7 


\title{
Tamara Slišković, PhD
}

Assistant Professor

University of Zagreb

Faculty of Economics and Business

E-mail: tamara.sliskovic@efzg.hr

Orcid: https://orcid.org/0000-0001-7925-8909

\section{Martina Solenički, PhD}

Assistant Professor

University of Zagreb

Faculty of Economics and Business

E-mail: mnakic@efzg.hr

Orcid: https://orcid.org/0000-0001-6380-1700

\section{Marija Beg, PhD}

Assistant Professor

University of Zagreb

Faculty of Economics and Business

E-mail: mbeg@efzg.hr

Orcid: https://orcid.org/0000-0002-7897-8055

\section{0 - YEAR OF SHOCKS - ASSESSMENT OF IMPACTS ON DWELLING PRICES IN CROATIA}

\begin{abstract}
The past year (2020) was marked by shocks that shook the Croatian economy in various spheres. First and foremost, the Covid-19 pandemic and consequently full and/or partial economic lockdown initially slowed down economic activity and then resulted in record negative GDP growth rates. Immediately after the declaration of the world pandemic, the capital of Croatia was hit by another unforeseen shock in the form of a strong earthquake. This paper assesses the effects of these events on Croatian dwelling prices, but also looks into the effects in individual regions (Zagreb, Adriatic and others). At the same time, the effect of housing loan subsidies, which is not exclusively related to 2020, is being assessed. The hedonic model of estimating the requested and achieved housing prices showed that the pandemic is not significantly related to housing price developments in Croatia, while housing loan subsidies can be linked to rising prices in certain market segments. Also, according to the analysis results, the earthquake in Zagreb can be related to the prices growth in the segment of newly built dwellings.
\end{abstract}

Keywords: dwelling prices, hedonic model, Covid-19, housing loan subsidies, earthquake

JEL classification: $R 21, R 32, R 38, O 18$ 